\title{
Synovial tissue macrophages and joint erosion in rheumatoid arthritis
}

\author{
Ghada Yanni, Alex Whelan, Conleth Feighery, Barry Bresnihan
}

\begin{abstract}
Objectives-To analyse the mononuclear cell populations in synovial membrane biopsies obtained before treatment from patients with rheumatoid arthritis (RA) and to correlate the findings with the degree of joint damage occurring over one year.

Methods-Multiple needle biopsy specimens were obtained from inflamed knee joints on entry to the study. The tissue samples were examined using immunohistochemical techniques. The degree of joint damage was estimated using the Larsen radiological index.
\end{abstract}

Results-Twelve patients were studied. It was observed that there was a significant correlation between the number of synovial tissue macrophages and the degree of joint erosion over one year $(r=0.66 ; p=0.04)$. The synovial lining layer contained large numbers of macrophages and the cellularity of the lining layer correlated significantly with the number of macrophages infiltrating the sublining areas $(r=0.65 ; p=0.01)$. Finally, the cellularity of the lining layer correlated with the synovial fluid levels of interleukin-6 $(r=0 \cdot 66 ; p=0 \cdot 04)$. The radiological course did not correlate with infiltrating $T$ or $B$ lymphocyte populations, but did correlate with other previously identified indicators of the clinical course, including a high index of disease activity and IgA rheumatoid factors levels.

Conclusion-This study suggests that synovial tissue macrophages play a critical role in the pathogenesis of joint erosion in RA.

Department of

Rheumatology,

University College and

St Vincent's Hospital,

Dublin, Ireland

G Yanni

B Bresnihan

Department of

Immunology,

University of Dublin

and St James's

Hospital,

Dublin, Ireland

A Whelan

C Feighery

Correspondence to:

Dr Barry Bresnihan,

Department of

Rheumatology,

St Vincent's Hospital

Dublin 4, Ireland.

Accepted for publication

19 October 1993
(Ann Rheum Dis 1994; 53: 39-44)

Rheumatoid arthritis (RA) is a chronic inflammatory disease with a variable clinical course and unpredictable outcome. In the synovium, large numbers of $\mathrm{T}$ and $\mathrm{B}$ lymphocyte populations and monocyte/macrophages migrate from the peripheral circulation through altered vascular endothelium. ${ }^{1}$ Many inflammatory products such as oxygen-free radicals, prostaglandins, cytokines and autoantibodies are secreted into the synovial tissues by the infiltrating mononuclear cells. Some controversy surrounds the relative contributions of the various cell populations to the disease process. $^{2-4}$ The cumulative effect of synovial inflammation is represented by the increasing degree of joint erosion which may be demonstrated radiologically. Several studies have sought to identify clinical and laboratory features of RA which might predict the radiological course. ${ }^{5}$ Among the features which have been repeatedly associated with more rapid or extensive joint erosion are greater disease activity in the early stages, ${ }^{67}$ the appearance of nodules $^{810}$ and serum levels of IgM- $-^{6-8}{ }^{11-13}$ and IgA-rheumatoid factor (RF). ${ }^{14-18}$

Previous studies seeking predictors of the radiological course in $\mathrm{RA}$ have not included immunohistochemical analysis of the synovial membrane. It is entirely appropriate to study synovial immunohistochemistry as the synovial membrane contains all the interrelated cellular and biochemical elements which lead to tissue destruction. We have previously documented the degree of immunohistological variation of synovitis in patients with active untreated RA. ${ }^{19}$ Thus in such patients, obtaining multiple needle biopsy specimens permits the quantification of several immunohistochemical parameters. Moreover, we have also demonstrated significant correlations between the immunohistological features in the biopsy samples and clinical and immunological measurements of disease activity. ${ }^{20}$ The present study extends these observation and is the first to identify immunohistological features in the synovial membrane which might be associated with a more aggressive radiological course. Synovial membrane biopsies and synovial fluid samples were obtained at the onset of the study from patients with clinically active RA who were presenting to a rheumatology service for the first time. Their disease course was followed for one year. Relationships between radiological progression and high disease activity scores at presentation and levels of IgA-RF were confirmed. Following immunohistological analysis a positive correlation was observed between the number of synovial tissue macrophages and the degree of radiological deterioration.

\section{Methods}

PATIENTS

All patients were selected from those referred to the Department of Rheumatology, St Vincent's Hospital, Dublin. Consecutive patients with a diagnosis of active seropositive $\mathrm{RA}^{21}$ were invited to participate in the study. All patients were required to have active inflammation in at least one knee joint. Patients who had previously received diseasemodifying anti-rheumatic drugs (DMARDs), immunosuppressive agents and oral or intra- 
articular corticosteroids were excluded. All patients gave their written consent to participate in the study. The study was approved by the St Vincent's Hospital Ethical Committee.

CLINICAL, LABORATORY AND RADIOLOGICAL ASSESSMENTS

Disease activity was measured using six standard clinical variables: duration of morning stiffness, pain visual analogue scale, grip strength, Ritchie articular index, ${ }^{22}$ haemoglobin and Westergren erythrocyte sedimentation rate (ESR). From these parameters a mean index of disease activity (IDA) was calculated. ${ }^{23}$ All clinical assessments were performed by the same physician (GY). Patients were assessed on entry to the study and after one year follow up. Treatment decisions were made by the physician in overall charge of the patients' care. During the period of follow up, 11 of the 12 patients received intramuscular gold salts for periods ranging between two and twelve months, three patients received sulphasalazine, two methotrexate and three low-dose corticosteroids.

Radiological assessments were performed at entry into the study and one year later. All $x$ rays were scored 'blind' (by GY) on two separate occasions with an interval of three months between the two assessments. No statistically significant difference was observed between the two readings when the Wilcoxon rank sum test was applied. The Larsen $x$ ray index of hands, wrists and feet and erosion scores of proximal interphalangeal and metacarpophalangeal joints were used to assess radiological damage. ${ }^{24}$ Radiological progression was estimated by subtracting the scores recorded at entry from the one year follow up Larsen index.

SYNOVIAL BIOPSY AND SYNOVIAL FLUID ASPIRATION

Synovial fluid was aspirated from an inflamed knee joint at the time of needle biopsy. Biopsy was performed using a Williamson-Holt synovial biopsy needle (Shrimpton and Fletcher Needle Industries, Redditch, Worcestershire, UK) under sterile conditons ${ }^{24}$ after local anaesthesia using $2 \%$ lignocaine had been administered. To facilitate the biopsy procedure $20 \mathrm{ml}$ of sterile saline was instilled in each joint. Multiple synovial samples were obtained from as wide a range as possible. Where only one joint was involved the biopsies were obtained from the affected side; where both knees were involved the biopsy was performed on the more severely affected side.

MONOCLONAL ANTIBODY STAINING OF TISSUE SECTIONS

Synovial tissue samples were placed in optimal temperature cutting compound (Miles Laboratories, Naperville, IL) and snap frozen in isopentane using liquid nitrogen. Six micron sections were then cut from each biopsy, mounted on gelatin coated slides, air dried overnight and finally fixed in acetone for 10 minutes before wrapping in tin foil to store at $-70^{\circ} \mathrm{C}$. Slides were allowed to thaw at room temperature for 15 minutes before unwrapping. The sections were fixed in acetone for 10 minutes before labelling with the monoclonal antibodies anti-Leu 1 (CD5), anti-Leu 2a (CD8), anti-Leu 3a (CD4), antiLeu 18 (CD45RA), anti-Leu 14 (CD22) and anti-Leu M3 (CD14) (Becton Dickinson Monoclonal Antibody Center, Sunnyvale, CA), anti-Pcal (Coulter, Luton, UK) to identify plasma cells, and anti-UCHL1 (CD45RO) (gift of Professor Beverley, ICRF Human Tumour Immunology Group, University College, London, UK). A standard 3 stage immunoperoxidase technique was applied. ${ }^{25}$ Colour was developed by immersing the slides in a solution of $0.05 \% \mathrm{wt} / \mathrm{vol} 3,3$ diaminobenzidine tetrachloride (Sigma Chemical, St Louis, MO), $0.04 \% \mathrm{wt} /$ volt nickel chloride and $0.03 \%$ hydrogen peroxide in $0.01 \mathrm{M}$ phosphate buffer saline $\mathrm{pH} 7 \cdot 2$.

\section{HISTOLOGICAL SCORING}

Tissue sections from each of the synovial samples were coded and were examined by a single observer (GY) with the aid of a graticule at a magnification of $\times 400$. Only sections with an identifiable synovial lining layer were assessed.

Synovial lining layer thickness The thickness of the lining layer was quantified according to cell depth. For each patient the entire length of the lining layer in each sample was examined. For each field examined three readings were recorded: one from each of the margins and a third from the centre of the field. The mean value per high power field was derived from all the recorded readings from each patient.

Mononuclear cell infiltration Sections from each of the samples obtained from every patient were examined. The total number of positively staining cells per field in the sublining areas was recorded. The mean number of cells per $\mathrm{mm}^{2}$ was calculated after all of the sections from each of the patients had been analysed.

MEASUREMENT OF RHEUMATOID FACTORS AND IMMUNOGLOBULINS

Immunoglobulins (Igs) and IgM and IgA RFs were measured in synovial fluids using a standard ELISA method. ${ }^{26}$ Human IgG was used to detect IgM-RF and IgA-RF. Flatbottomed microtitre plates (Nunc, Copenhagen, Denmark) were coated (100 $\mu \mathrm{l} /$ well) by overnight incubation with human IgG ( $1 \mathrm{mg} / \mathrm{ml}$ ) in a carbonate-bicarbonate buffer, $\mathrm{pH} 9 \cdot 6$. The following day, plates were washed five times with phosphate buffered salineTween 20 (PBS-Tween), pH 7·4, and appropriate sample dilutions made up in PBS-Tween were added (100 $\mu \mathrm{g} /$ well). All samples were assayed in triplicate. Following a 30 minute incubation at $37^{\circ} \mathrm{C}$, plates were washed again with PBS-Tween. Commercially available peroxidase-conjugated class-specific antisera 
Table 1 Clinical and demographic features of patients with rheumatoid arthritis.

\begin{tabular}{lccc}
\hline & At onset of study & At follow up & p value \\
\hline Total number & 12 & & \\
Number female & 6 & & \\
Mean age (range) years & $49(24-66)$ & & \\
Mean disease duration (range) months & $22(4-66)$ & $0(0-120)$ & $0 \cdot 009$ \\
Duration of morning stiffness (minutes) & $90(10-360)^{\star}$ & $196(58-400)$ & $0 \cdot 10$ \\
Grip strength (mm Hg) & $115(54-340)$ & $2(0-8)$ & $0 \cdot 15$ \\
Pain (visual analogue scale, cm) & $5(0-10)$ & $12(0-41)$ & $0 \cdot 02$ \\
Ritchie articular index & $27(12-49)$ & $12 \cdot 5(11 \cdot 1-15 \cdot 8)$ & $0 \cdot 06$ \\
Haemoglobin (gr/dl) & $11 \cdot 9(10 \cdot 0-14 \cdot 2)$ & $25(2-45)$ & $0 \cdot 004$ \\
ESR (mm hr) & $70(6-96)$ & $1 \cdot 66(1 \cdot 0-2 \cdot 3)$ & $0 \cdot 0004$ \\
Composite index of disease activity & $2 \cdot 7(2 \cdot 3-3 \cdot 2)$ & &
\end{tabular}

*All results expressed as median (range).

(diluted 1:10,000 in PBS-Tween; $100 \mu \mathrm{g} /$ well) were used to quantify the different RFs: goat $\mathrm{F}(\mathrm{ab})_{2}$ anti-human $\operatorname{IgM}$ ( $\mu$ chain specific; Cappel, West Chester, PA); goat $\mathrm{F}(\mathrm{ab})_{2}$ antihuman IgA ( $\alpha$ chain specific; Cappel). $F(a b)_{2}$ antisera were used to avoid nonspecific binding through the $\mathrm{Fc}$ fragment. Plates were then incubated at $37^{\circ} \mathrm{C}$ for 30 minutes and washed for a final time with PBS-Tween. Substrate solution (o-phenylenediamine) was added $(100 \mu \mathrm{l} /$ well) and the reaction was stopped by the addition of $2.5 \mathrm{M} \mathrm{H}_{2} \mathrm{SO}_{4}(100 \mu \mathrm{l} /$ well $)$ after a predetermined optimal time (for the IgA-RF ELISA, 10 minutes; for the IgM-RF ELISA, 20 minutes). Plates were read on a Dynatech spectrometer at $490 \mathrm{~nm}$ wavelength.

Standard curves were drawn for IgM-RF, and values were calculated, in $\mathrm{IU} / \mathrm{ml}$, using pooled RA sera that had been calibrated against a known World Health Organisation IgM-RF standard (Medlabs, Dublin, Ireland). IgA-RF levels were calculated in units of optical density (OD).

\section{IL-1 BETA AND IL-6 MEASUREMENTS}

IL-1 beta and IL-6 were measured using an immunoradiometric (IRMA) assay (IL-1 betaIRMA, IL-6-IRMA, Medgenix Diagnostics, Brussels, Belgium). This assay is based on the oligoclonal system in which several monoclonal antibodies (Mabs) directed against distinct epitopes of IL-1 beta or IL-6 are used. The capture antibodies (Mabs 1), are attached to the lower and inner surface of the plastic tubes. Standards of samples added to the tubes will show low affinity for Mabs 2, the significant antibodies. Addition of Mabs 2, labelled with I-125, complete the oligoclonal system and allow quantification of the bound cytokine. After washing, the remaining radioactivity bound to the tubes reflects the antigen concentration. The use of several distinct Mabs avoids hyperspecificity common to two site IRMA. Coated tubes were labelled in duplicate for

Table 2 Rheumatoid factor and cytokine measurements in synovial fluid and correlations with radiological deterioration.

\begin{tabular}{lcll}
\hline $\begin{array}{l}\text { Synovial fluid } \\
\text { component }\end{array}$ & Measurement & \multicolumn{2}{l}{ Correlation with radiological deterioration } \\
\cline { 3 - 4 } & & rvalue & $p$ value \\
\hline IgA RF (EI) & $3 \cdot 05(1 \cdot 2-5 \cdot 8)^{\star}$ & $0 \cdot 80$ & $0 \cdot 01$ \\
IgM RF (IU/ml) & $128(44-740)$ & $0 \cdot 47$ & $0 \cdot 10$ \\
IL-1 $\beta(\mathrm{pg} / \mathrm{ml})$ & $56 \cdot 5(40-240)$ & $0 \cdot 43$ & $0 \cdot 12$ \\
IL-6 $(\mathrm{ng} / \mathrm{ml})$ & $61(3 \cdot 7-865)$ & $0 \cdot 18$ & $0 \cdot 70$ \\
\hline
\end{tabular}

${ }^{\star}$ Results expressed as median (range). each standard, synovial fluid and control samples. The complete contents of each tube was aspirated and washed. The tubes were counted in a gamma counter for 60 seconds. Concentrations of IL- 1 beta and IL- 6 were obtained from a standard curve. The results were expressed in $\mathrm{pg} / \mathrm{ml}$.

\section{STATISTICAL ANALYSIS}

All results were expressed as mean (SD). Nonparametric statistics were used in all statistical analyses because of the small sample sizes involved. Differences between the observations at entry to the study and one year follow up were tested using the Mann Whitney Wilcoxon test. The correlation between parameters was examined by the Kendall rank test.

\section{Results}

Twelve patients were recruited for the study. Their clinical features are documented in table 1. The clinical measurements demonstrate that this cohort of patients had moderately active disease on entry to the study with a median Ritchie articular index of 27 , median duration of morning stiffness 90 minutes and a median ESR of $70 \mathrm{~mm} / \mathrm{hr}$. High levels of IgM (mean $1719 \mu \mathrm{g} / \mathrm{ml}), \operatorname{IgA}(7513 \mu \mathrm{g} / \mathrm{ml})$ and IgG $(22025 \mu \mathrm{g} / \mathrm{ml})$ were measured in the synovial fluids. Table 2 includes the synovial fluid levels of rheumatoid factors, IL-1 $\beta$ and IL-6. Adequate synovial tissue was obtained by needle biopsy from 11 patients. Typical appearances were observed. The immunohistological details are demonstrated in table 3. Thus mononuclear cell infiltration was present in all biopsy samples. Multiple focal perivascular mononuclear cell aggregates were present in one patient and a diffuse pattern of mononuclear cell infiltration seen in the remainder. All samples demonstrated increased accumulation of mononuclear cells in the synovial lining layer. Table 4 documents the total numbers of biopsy specimens with intact lining and sublining layers available for analysis from each patient. The median numbers of tissue macrophages per $\mathrm{mm}^{2}$ are also included. The immunohistological details are demonstrated in table 3.

All patients were treated as thought appropriate by their rheumatologists and reassessed clinically and radiologically after one year. Several clinical parameters had improved significantly (table 1): duration of morning stiffness $(p=0.009)$, Ritchie articular index $(p=0.02), \operatorname{ESR}(p=0.004)$ and the composite index of disease activity $(p=0.0004)$. The remaining parameters also improved, but not significantly. Despite the measured clinical improvement, radiological deterioration was noted in eight patients (table 4).

Factors which might have predicted radiological deterioration were sought by correlating initial clinical parameters, synovial fluid factors and immunohistological features with the degree of radiological deterioration. Positive correlations with the presenting composite index of disease activity $(r=0.68, p=0.04)$ 
Table 3 Synovial tissue cell populations and correlations with radiological deterioration.

\begin{tabular}{|c|c|c|c|c|}
\hline \multirow{2}{*}{\multicolumn{2}{|c|}{ Cell population }} & \multirow[t]{2}{*}{ Number/mm $m^{2}$ (range) } & \multicolumn{2}{|c|}{ Correlation with radiological deterioration } \\
\hline & & & rvalue & $p$ value \\
\hline \multirow{4}{*}{$\begin{array}{l}\text { Macrophage: } \\
\text { T cell: }\end{array}$} & CD14+ & $508(117-845)^{\star}$ & 0.66 & 0.04 \\
\hline & CD5+ & $620(65-135)$ & 0.32 & 0.30 \\
\hline & CD4+ & $268(93-1012)$ & 0.43 & 0.13 \\
\hline & & $299(17-693)$ & 0.41 & $0 \cdot 10$ \\
\hline \multirow{3}{*}{\multicolumn{2}{|c|}{$\begin{array}{l}\text { B cell: } \quad \text { CD22+ } \\
\text { Plasma cell: Pca 1+ } \\
\text { Lining layer thickness: }\end{array}$}} & $56(0-749)$ & $0 \cdot 20$ & 0.50 \\
\hline & & $54(0-146)$ & 0.55 & $0 \cdot 10$ \\
\hline & & $4(2-32)$ & $-0 \cdot 18$ & 0.61 \\
\hline
\end{tabular}

*Cell numbers expressed as median (range).

and synovial fluid levels of IgA-RF $(r=0 \cdot 80$, $\mathrm{p}=0.01$ ), but not IgM-RF, were demonstrated (table 2). Of particular interest was the demonstration of a positive correlation between radiological deterioration and the number of infiltrating macrophages $(r=0.66 ; p=0.04)$ (table 3). No significant correlations with any of the $\mathrm{T}$ cell (CD5+, CD4+, CD8+, $\mathrm{CD} 45 \mathrm{RO}+$ and CD45RA+), B cell or plasma cell populations were demonstrated. As expected, the synovial lining layer contained large numbers of CD14+ cells and the cellularity of the lining layer correlated strongly with the numbers of CD14+ cells infiltrating the sublining areas $(r=0.65, p=0.01)$. Moreover, the cellularity of the lining layer also correlated with the levels of IL- 6 in the synovial fluid $(\mathrm{r}=0.66, \mathrm{p}=0.04)$.

\section{Discussion}

Twelve patients with uncontrolled seropositive RA were subjected to synovial fluid aspiration and synovial membrane biopsy as part of a one year prospective study. Two novel observations were made which may be important not only in identifying indicators of the radiological course but also in providing additional insight into the mechanisms of articular erosion. Firstly, there was a positive correlation between the number of infiltrating synovial tissue macrophages in biopsies obtained at the onset of the study and the degree of radiological deterioration over the following year. The statistical significance of the correlation was $p=0 \cdot 04$. The relatively low $p$ value might be due to the small size of the study group. No correlation between the number of other infiltrating mononuclear cell populations and radiological deterioration was observed. A previous study suggested that some immunohistochemical features observed in biopsy

Table 4 Synovial tissue macrophages and joint erosion.

\begin{tabular}{|c|c|c|c|c|}
\hline \multirow[t]{2}{*}{ Patient } & \multirow{2}{*}{$\begin{array}{l}\text { Number of } \\
\text { tissue samples }\end{array}$} & \multirow{2}{*}{$\begin{array}{l}\text { Tissue macrophages } \\
\text { median (range) } / \mathrm{mm}^{2}\end{array}$} & \multicolumn{2}{|c|}{ Larsen scores } \\
\hline & & & Entry & 1 year \\
\hline 1 & 4 & $470(98-1484)$ & 43 & 61 \\
\hline 2 & 5 & $609(196-980)$ & 36 & 36 \\
\hline 3 & 6 & $560(154-1050)$ & 129 & 144 \\
\hline 4 & 5 & $602(210-980)$ & 32 & 56 \\
\hline 5 & 5 & $49(0-490)$ & 38 & 48 \\
\hline 6 & 4 & $735(602-1190)$ & 64 & 86 \\
\hline 7 & 5 & $70(0-406)$ & 56 & 59 \\
\hline 8 & 4 & $350(140-840)$ & 147 & 147 \\
\hline 9 & $\mathrm{~F}^{\star}$ & - & 92 & 92 \\
\hline 10 & 6 & $154(10-406)$ & 42 & 46 \\
\hline 11 & 8 & $434(210-966)$ & 60 & NAt \\
\hline 12 & 6 & $140(0-770)$ & 30 & 42 \\
\hline
\end{tabular}

^F: biopsy failed, inadequate tissue. †NA: not available. specimens obtained from the knee joints of patients with untreated $R A$, broadly reflect contemporaneous clinical and immunological measures of disease activity. ${ }^{20}$ It was subsequently suggested that the degree of synovial lining layer thickness in knee joint specimens from a similar cohort of patients predicted the overall clinical outcome over one year. ${ }^{27}$ The present study observes a correlation between specific immuno-histochemical features in synovial specimens obtained from the knee joint and a general measure of radiological outcome.

In RA, synovial tissue macrophages migrate from the peripheral circulation and characteristically occupy the periphery of lymphoid follicles, extend through the interstitial areas and accumulate in large numbers with proliferating fibroblasts in the thickened lining layer. $^{28-30}$ The thickened lining layer may contain up to $80-100 \%$ cells of the macrophage lineage. ${ }^{31}$ It has been suggested that synovial tissue macrophages are crucial to the pathogenesis of articular destruction in RA. ${ }^{2}$ Macrophages secrete many inflammatory mediators relevant to rheumatoid synovitis; in some circumstances they are the principle source of IL- $6 .{ }^{32}{ }^{33}$ The correlation between the cellularity of the synovial lining layer and synovial fluid levels of IL- 6 observed in this study underscores the significance of the relationship between synovial macrophages and articular destruction. IL-6, which is also secreted by $\mathrm{T}$ and $\mathrm{B}$ lymphocytes, ${ }^{34}$ fibroblasts ${ }^{3536}$ and endothelial cells, ${ }^{37} 38$ has several known biological effects which may contribute to chronic inflammation in RA: by augmenting $T$ cell activation, ${ }^{39}{ }^{40}$ IL-2 receptor expression on $\mathrm{T}$ cells ${ }^{41}$ and the differentiation of cytotoxic $\mathrm{T}$ cells, ${ }^{42}$ by stimulating synovial B cells ${ }^{43}$ and by causing the acute phase protein response. ${ }^{44}$ IL-6 can be readily measured in sera and synovial fluids from patients with RA. ${ }^{43} 45-49$ In the synovial membrane, IL-6 production has been localised to macrophages, ${ }^{50}$ the cells in the lining layer ${ }^{51}$ and to $T$ cells in the lymphocyte rich aggregates. ${ }^{45} 52$ It has been argued that the IL- 6 localised to lymphocytes represents surface bound IL-6 produced by macrophages or fibroblasts. ${ }^{51}$ The present study did not address the source of synovial fluid IL-6 which might have originated in cells other than the synovial tissue macrophages.

The second novel observation in this study was the significant correlation between synovial fluid levels of IgA-RF and the radiological course. This is in agreement with the correlation between serum levels of IgA-RF and increasing joint erosion observed by others. ${ }^{14-18}$ As significant positive correlations between levels of IgA-RF subclasses in serum and synovial fluid have been previously described, ${ }^{53}$ it is suggested that both serum and synovial fluid levels of IgA-RF may be useful laboratory predictors of the radiological course in RA. Although the mechanisms regulating $R F$ synthesis have not been clarified, a possible role for IL-6 has been suggested ${ }^{50}$ and a correlation between synovial fluid 
IL-6 activity and levels of IgA RF has been demonstrated. ${ }^{54}$ Thus the observations made in this study may be interrelated. If the findings are confirmed future therapeutic strategies which target synovial tissue macrophages and their products may be particularly rewarding.

We are grateful to Dr Oliver FitzGerald for his helpful comments and to Pauline Curran for preparing the manuscript.

This study was supported by a grant from The Health Research Board of Ireland.

1 Harris E D. Rheumatoid arthritis: pathophysiology and implications for therapy. $N$ Eng $\mathcal{F}$ Med 1990; 322: implications

2 Firestein G S, Zvaifler N J. How important are T cells in chronic rheumatoid synovitis? Arthritis Rheum 1990; 33: 768-73.

3 Strober S, Holoshitz J. Mechanisms of immune injury in rheumatoid arthritis: evidence for the involvement of $T$ cells and heat-shock protein. Immunol Rev 1990; 118: 233-55.

4 Panayi G S, Lanchbury J S, Kingsley G H. The importance of the $\mathrm{T}$ cell in initiating and maintaining the chronic synovitis of rheumatoid arthritis. Arthritis Rheum 1992; 35: 729-35.

5 van der Heijde D M F M, van Riel P L C M, van Rijswijk M H, van de Putte L B A. Influence of prognostic features on the final outcome in rheumatoid arthritis: a review of the literature. Semin Arthritis Rheum 1988; 17: review of

6 Young A, Corbett M, Winfield J, et al. A prognostic index for erosive changes in the hands, feet and cervical spines in early rheumatoid arthritis. Brit $\mathcal{F}$ Rheumatol 1988; 27: 94-101.

7 van der Heijde D M F M, van Riel P L C M, van Leeuwen M A, van't Hof M A, van Rijswijk M H, van de Putte L B A. Prognostic factors for radiographic damage and $\begin{array}{llll}\text { physical disability in early rheumatoid arthritis: } & \text { a } \\ \text { prospective follow-up study of } 147 \text { patients. } B r & \mathcal{f}\end{array}$ Rheumatol 1992; 31: 519-25.

8 Masi A T, Maldonado-Cocco J A, Kaplan S B, Feigenbaum $S \mathrm{~L}$, Chandler R. Prospective study of the early course of rheumatoid arthritis in young adults: comparison of patients with and without rheumatoid factor positivity at patients with and identification of variable correlating with entry and identification of variable correlating
outcome. Semin Arthritis Rheum 1976; 4: 299-326.

9 Rasker J J, Cosh J A. The natural history of rheumatoid arthritis: a fifteen year follow-up study. The prognostic
significance of features noted in the first year. Clin significance of features note

10 Dawes P T, Fowler P D, Jackson R, et al. Prediction of progressive joint damage in patients with rheumatoid arthritis receiving gold or D-penicillamine therapy. Ann Rheum Dis 1986; 45: 945-9.

11 Cats A, Hazevoet $M$. Significance of positive tests for rheumatoid factor in the prognosis of rheumatoid arthritis. Ann Rheum Dis 1970; 29: 254-60.

12 Feigenbaum S L, Masi A T, Kaplan S B. Prognosis in rheumatoid arthritis. A longitudinal study of newly diagnosed younger adult patients. Am $\mathcal{F} \mathrm{Med}$ 1979; 66: diagnosed

13 Mottonen $\mathrm{T} T$. Prediction of erosiveness and rate of development of new erosions in early rheumatoid
arthritis. Ann Rheum Dis 1988; 47: 648-53.

14 Teitsson I, Withrington R H, Seifert M H, Valdimarsson $H$. Prospective study of early rheumatoid arthritis. 1 . Prognostic value of IgA rheumatoid factor. Ann Rheum Dis 1984; 4: 673-8.

5 Arnason J A, Jonsson T H, Brekkan A, Sigurionsson K, Valdimarsson $\mathrm{H}$. Relation between bone erosions and rheumatoid factor isotypes. Ann Rheum Dis 1987; 46: 380-4.

16 Eberhardt K B, Truedsson L, Pettersson H, Svensson B, Stigsson L, Eberhardt J L. Disease activity and joint damage in early rheumatoid arthritis: relation to IgG, IgA and IgM rheumatoid factor. Ann Rheum Dis 1990; 49: and $\lg M$

17 Eggelmeijer F, Offen H G, de Rooy H H, Dalma M R, Breedveld F C. Significance of rheumatoid factor isotypes in sero-ne. $43-6$.

18 van Zeben D, Hazes J M W, Zwinderman A T T, Cats A, van der Voort E A M, Breedveld F C. Clinical significance of rheumatoid factors in early rheumatoid arthritis: results of a follow-up study. Ann Rheum Dis 1992; 51: 1029-35.

19 Rooney M, Condell D, Quinlan W, et al. Analysis of the histological variation of synovitis in rheumatoid arthritis. Arthritis Rheum 1988; 31: 956-63.

20 Rooney M, Whelan A, Feighery C, Bresnihan B. The immunohistologic features of synovitis, disease activity and in-vitro IgM rheumatoid factor synthesis by blood mononuclear cells in rheumatoid arthritis. 7 Rheumatol 1989, 16: 459-67.
21 Arnett F C, Edworth S M, Bloch D A, et al. The American Rheumatism Association 1987 revised criteria for the classification of rheumatoid arthritis. Arthritis Rheum 1988; 31: 315-24.

22 Ritchie D M, Boyle J A, McInnes J M, et al. Clinical studies with an articular index for the assessment of joint tenderness in patients with rheumatoid arthritis. $Q \mathcal{O M} \mathrm{Med}$ 1958; 37: 393-406.

23 Mallya R K, Mace B E W. The assessment of disease activity in rheumatoid arthritis using a multivariation analysis. Rheum Rehab 1981; 20: 14-17.

24 Larsen A, Thoen J. Hand radiography of 200 patients with rheumatoid arthritis repeated after an interval of one year. Scand F Rheumatol 1987; 16: 395-401.

25 Mason D Y, Cordell J L, Abdulaziz Z, Naiem M, Bordenane G. Preparation of peroxidase: antiperoxidase (PAP) complexes for immunohistological labelling of 1114-1122.

26 Faith A, Pontesilli O, Unger A, Panayi G S, Johns P. ELISA assays for IgM and IgG rheumatoid factors. $\mathcal{F}$ Immunol Methods 1982; 55: 169-77.

27 Soden M, Rooney M, Whelan A, Feighery C, Bresnihan B. Immunohistologic analysis of the synovial membrane Immunohistologic analysis of the synovial membrane seeking predictors of the clinical course
arthritis. Ann Rheum Dis 1991; 15: 673-6.

28 Ishikawa $\mathrm{H}$, Ziff $M$. Immunoreactive cells in the rheumatoid synovial membrane. Arthritis Rheum 1976; 19: 1-14

29 Iguchi T, Ziff M. Electron microscopic study of rheumatoid synovial vasculature. Intimate relationship between tall endothelium and lymphocyte aggregation. $\mathcal{f}$ Clin Invest 1986; 77: 355-61.

30 Henderson B, Edwards J C W. Structure of synovial lining. In: Henderson $\mathrm{B}$, Edwards J C W, eds. The Synovial Lining in Health

31 Poulter C W, Duke O, Hobbs S, Janossy G, Panayi G S. Histochemical discrimination of HLA-DR positive-cell populations in the normal and arthritis synovial lining. Clin Exp Immunol 1982; 48: 381-8.

32 Aarden L A, de Groot E R, Schaap O L, Lansdorp P M. Production of hybridoma growth factor by human monocytes. Eur F Immunol 1987; 17: 1411-16.

33 van Damme J, van Beauman J, Schapp D L, Lansdorp P M. Production of hybridoma growth factor by human monocytes. Eur f Immunol 1987; 17: $1411-20$.

34 Horii Y, Muraguchi A, Seumatsu S, et al. Regulation of BSF-2 IL- 6 production by human mononuclear cells. Macrophage-dependent synthesis of BSF-2 IL-6 by T cells. F Immunol 1988; 141: 1529-35.

35 van Damme J, Cayphan S, Opdenakker G, Billiau A, van Snick J. Interleukin-1 and poly $(\mathrm{rl})$ poly $(\mathrm{RC})$ induce production of a hybridoma growth factor by human production of a hybridoma growth facto

36 Kohase M, Henriksen-Destefano D, May L T, Vileek J, Sehgal B. Induction of beta-interferon by tumour necrosis Sehgal B. Induction of beta-interferon by tumour necrosis factor: a homeostatic mechanism

37 Astaldi G C B, Janssen M C, Lansdorp P, Willems C, Zeiijlemaker W P, Oosterhof F. Human endothelial culture supernatant (HECs): a growth factor for hybridomas. F Immunol 1980; 125: 1411-24.

38 Jirik F R, Podor T J, Hirano T, et al. Bacterial lipopolysaccharide and inflammatory mediators augment IL-6 excretion by human endothelial cells. $\mathcal{F}$ Immunol 1989; 142: 144-7.

39 Lotz M, Jirik F, Kabouridis P, et al. B cell stimulating factor 2 /interleukin 6 is a costimulant for human thymocytes and $T$ lymphocytes. $₹$ Exp Med 1988; 167: 1253-8.

40 Tosato $\mathrm{G}$, Pike $S$ E. Interferon- $\beta 2 /$ interleukin 6 is a costimulant for human $T$ lymphocytes. F Immunol 1988 ; 141: 1556-62.

41 Noma T, Mitzuta T, Rosen A, Hirano T, Kishimoto T, Honjo T. Enhancement of interleukin-2 receptor expression on $T$ cells by multiple $B$ lympotropic lymphokines. Immunol Lett 1987; 15: 249-53.

42 Takai Y, Wong G G, Clark S C, Burakoff J, Herrmann S H. B cell stimulatory factor-2 is involved in the differentiation of cytotoxic T lymphocytes. $\mathcal{F}$ Immunol 1988; 140: 508-12.

43 Guerne P A, Zuraw B L, Vaughan J H, Carson D A, Lotz $M$. Synovium as a source of interleukin-6 in vitro: contribution to local and systemic manifestations of arthritis. $\mathcal{F}$ Clin Invest 1989; 83: 585-92.

44 Gauldie J, Richards C, Harnish D, Lansdorp P, Baumann $H$. Interferon $\beta 2 / B$ cell stimulatory factor type 2 shares identity with monocyte-derived hepatocyte type 2 shares identity with monocyte-derived hepatocyte stimulating factor and regulates the major acute phase protein response in

45 Hirano T, Matsuda T, Turner $M$, et al. Excessive production of interleukin-6/B cell stimulatory factor-2 in rheumatoid arthritis. Eur $\mathcal{f}$ Immunol 1988; 18: 1797-1801.

46 Waage A, Kaufmann C, Espevik T, Husby G. Interleukin-6 in synovial fluid from patients with arthritis. Clin Immunol Immunopathol 1989; 30: 394-8.

47 Houssiau F A, Devogelaer J P, van Damme J, Nagant de Deuxchaisnes C, van Snick J. Interleukin-6 in synovial fluid and serum of patients with rheumatoid arthritis and other inflammatory arthritides. Arthritis Rheum 1988; 31 : 784-8. 
48 Bhardwaj N, Sanlhanam U, Lau L L, et al. IL-6/IFN-B ${ }_{2}$ in synovial effusions of patients with rheumatoid arthritis and other arthritides: identification of several isoforms and studies of other cellular sources. F Immunol 1989; 143: 2153-9.

49 Miyasaka N, Sato K, Hushimoto J, et al. Constitutive production of interleukin-6/B cell stimulatory factor- 2 from inflammatory synovium. Clin Immunol Immunopatho $1989 ; 52: 238-47$

50 Field $M$, Chu C, Feldman $M$, Maini $R \quad N$ Interleukin-6 localization in the synovial membran in rheumatoid arthritis. Rheumatol Int 1991; 11 $45-50$
51 Firestein G S, Alvaro-Garcia J M, Maki R. Quantitative analysis of cytokine gene expression in rheumatoid arthritis. F Immunol 1990; 144: 3347-53.

52 Wood N C, Symons J A, Dickens E, Duff G W. In situ hybridization of IL-6 in rheumatoid arthritis. Clin Exp Immunol 1992; 87: 183-9.

53 Offen $H G$, Daha $M$ R, van Laar $J$, de Rooy $H_{H}$ Breedveld F C. Subclass distribution and size of human IgA rheumatoid factor at mucosal and nonmucosal sites. Arthritis Rheum 1991; 34: 831-9.

54 Sawada T, Hirohata S, Inoue S, Ito K. Correlations between rheumatoid factor and interleukin- 6 activity in synovial fluids from patients with rheumatoid arthritis. Clin Exp Rheumatol 1991; 9: 363-8. 